\title{
AHR wt Allele
}

National Cancer Institute

\section{Source}

National Cancer Institute. AHR wt Allele. NCI Thesaurus. Code C52506.

Human AHR wild-type allele is located in the vicinity of 7p15 and is approximately $48 \mathrm{~kb}$ in length. This allele, which encodes aryl hydrocarbon receptor protein, plays a role in both the mediation of the biochemical and toxic effects of halogenated aromatic hydrocarbons and the regulation of the cell cycle. 